Etnográfica

Revista do Centro em Rede de Investigação em

Antropologia

vol. 22 (1) | 2018

Vol. 22 (1)

\title{
Anthropology and ethnography: the transnational perspective on migration and beyond
}

Antropologia e etnografia: a perspectiva transnacional sobre a migração e para além dela

\section{Bela Feldman-Bianco}

\section{(2) OpenEdition}

Journals

Electronic version

URL: https://journals.openedition.org/etnografica/5203

DOI: 10.4000/etnografica.5203

ISSN: 2182-2891

\section{Publisher}

Centro em Rede de Investigação em Antropologia

\section{Printed version}

Date of publication: 1 February 2018

Number of pages: 195-215

ISSN: 0873-6561

\section{Electronic reference}

Bela Feldman-Bianco, "Anthropology and ethnography: the transnational perspective on migration and beyond", Etnográfica [Online], vol. 22 (1) | 2018, Online since 17 May 2018, connection on 20 January 2022. URL: http://journals.openedition.org/etnografica/5203 ; DOl: https://doi.org/10.4000/ etnografica. 5203

\section{(c) (;) (9)}

Etnográfica is licensed under a Creative Commons Attribution-NonCommercial 4.0 International License. 


\section{Anthropology and ethnography: the transnational perspective on migration and beyond}

\section{Bela Feldman-Bianco}

As a long time interlocutor of the authors of Nations Unbound (Basch, Glick Schiller and Szanton Blanc 1994), I intend to examine the emergence of the transnational perspective on migration and its developments. Based upon my ongoing comparative research project on the secular migrations of the Portuguese to New Bedford, MA (USA), and São Paulo (Brazil), and the more recent migration of Brazilians to Lisbon, Portugal, I will indicate the historical conjuncture that led to the formulation of this paradigm. I further specify the reconfigurations of this paradigm and resulting advances for the study of migrants in cities (Çağlar and Glick Schiller 2011 ) and at the same time argue for the need of a broader notion of migrations and displacements (Feldman-Bianco 2015). I claim that this broader notion will allow us to articulate and, thus, understand the varieties, scales and spaces of displacement (and immobility) as part of an integrated logic for producing inequalities in the current conjuncture of global capitalism.

KEYWORDS: anthropology, ethnography, transnational migration, migration and displacements, global capitalism.

Antropologia e etnografia: a perspectiva transnacional sobre a migração e para além dela - Como interlocutora de longa data das autoras de Nations Unbound (Basch, Glick Schiller e Szanton Blanc 1994), examino a emergência da perspectiva transnational das migrações e seus desenvolvimentos. Com base em meu projeto comparativo sobre as migrações seculares dos portugueses para New Bedford, MA (USA) e São Paulo (Brasil) e sobre as migrações mais recentes de brasileiros para Lisboa (Portugal), indico a conjuntura histórica de formulação desse paradigma. Para além de especificar as reconfigurações desse paradigma e resultantes avanços para o estudo das migrações na cidade (Çağlar e Glick Schiller 2011), defendo a necessidade de uma noção mais ampla de migrações e deslocamentos (Feldman-Bianco 2015). Argumento que essa noção mais ampla nos permite articular e, assim, entender as variedades, escalas e espaços dos deslocamentos (e imobilidades) como parte de uma lógica integrada para produzir desigualdades na atual conjuntura do capitalismo global.

PALAVRAS-CHAVE: antropologia, etnografia, migração transnational, migração e deslocamentos, capitalismo global.

FELDMAN-BIANCO, Bela (bfb@uol.com.br) - Unicamp, Brazil. 


\section{INTRODUCTION}

As Eric Wolf aptly stated, concepts and models should be treated as tools that we can use to periodically review our ideas and conduct "a critical evaluation of the ways we pose and answer questions, and of the limitations we might bring to that task" (Wolf 1988: 752). ${ }^{1}$ In this respect, John Comaroff's view of anthropology as a praxis highlights the relevance of fieldwork conducted in specific times and places for formulating, refining and changing concepts and paradigms. ${ }^{2}$ Thus, ethnographies provide us with tools for the continual reevaluation of our ideas.

From this viewpoint, and as a long time interlocutor of the authors of Nations Unbound: Transnational Projects, Postcolonial Predicaments, and Deterritorialized Nation-States (Basch, Glick Schiller and Szanton Blanc 1994), I intend to examine the emergence of the transnational perspective on migration and some of its developments. Based on my ongoing comparative research project on the secular migrations of the Portuguese to New Bedford, Massachusetts, in the United States, and São Paulo, Brazil, and the more recent migration of Brazilians to Lisbon, Portugal, I will explore the relations between ethnography and the historical conjuncture that led to the formulation of this paradigm. I will further specify its reconfigurations for the study of migrants in cities (Çağlar and Glick Schiller 2011). At the same time, I will argue for the need for a broader notion of migrations and displacements capable of allowing us to understand and expose the similar patterns underlying the varieties, scales and spaces of displacement (and immobility) as part of an integrated logic for producing inequalities in the current conjuncture of global capitalism.

\section{DEVELOPMENT OF THE TRANSNATIONAL PERSPECTIVE}

\section{ON MIGRATION}

In the 1980s, Nina Glick Schiller, Linda Basch and Cristina Blanc-Szanton formulated the transnational perspective on migration, based on fieldwork conducted among so-called "new immigrants" from former colonies who settled in US cities in a historic conjuncture marked by global political and

1 This is a revised and expanded version of a paper presented at the workshop "Nations Unbound: twenty years later" held at the Free University of Amsterdam, October 27-30, 2014, and also at the panel "Nations Unbound: conjuncture, temporality and agency" at the 2014 Annual Meetings of the American Anthropological Association, in Washington, DC. The aim of these events was "to bring key anthropologists together to place the transnational migration paradigm and the ethnographies it has stimulated within the contemporary political economic, and social conjunction" (Glick Schiller 2014: 1).

2 According to John Comaroff, perceiving anthropology as an (in)discipline, that is to say as praxis, reveals that our epistemological operations, "belong to the realm of methodology, entailing at the same time an orientation towards the nature of knowledge, its philosophy and its notions of truth, fact and values" (2010: 529). 
economic restructuring, government policies favoring chain migration, and national reconfigurations. Their book Nations Unbound (Basch, Glick Schiller and Szanton Blanc 1994), based on case studies conducted among transmigrants from Haiti, Saint Vincent, Grenada and the Philippines, was the first full-length ethnography to respond to questions that arose in the 1980s concerning the global political economy, transmigration, nation-state redefinitions and migration regimes. The authors called attention to the transmigrants' social fields, which linked localities and countries in a single construction through networks of social relations that transposed national borders. They examined transmigrants as subjects and actors within the hegemonic processes of at least two nations. They also transposed the field of ethnicity well beyond the analysis of its cultural dynamics. Their transnational paradigm enabled them to analyze how migrants confront structures of unequal power and discrimination in their lives that cross state borders. From that viewpoint, they challenged the prevailing focus on the "uprooted" and traditional views on migration, nationalism and citizenship. Capturing the specific processes occurring in the last decades of the $20^{\text {th }}$ century, they highlighted the national redefinitions that at the time transmuted, either by rhetoric or by law, former colonies, which were positioned in the world political economy as exporters of immigrants, into nations based on population rather than territory.

Given the excellence of their scholarship, Glick Schiller, Basch and Szanton-Blanc tested and refined their theoretical paradigm through a series of seminars, panels and symposiums. In 1990, they organized a major symposium of the New York Academy of Sciences entitled "Towards a new perspective on migration: class, race, ethnicity and nationalism reconsidered," and challenged anthropologists who were conducting fieldwork on immigrants in the United States to examine their data through the lenses of an emerging transnational perspective of migration. ${ }^{3}$ In 1994, they led the Wenner-Gren symposium entitled "Transnationalism, nation-state building, and culture," which brought together scholars from the US, Europe and Latin America who were defining and using the term transnationalism from different viewpoints and in contrastive ethnographic contexts:

"to engage in a more global conversation that may bring greater clarity to the concept of transnationalism, specifying its critical elements and exploring the ways it relates to the current state of the global economy and the politics of nation-building. We need to explore the relationship among global capitalism, the exercise of state power, and the construction and reformulation of culture" (Szanton-Blanc, Basch and Glick Schiller 1994: 1).

3 This symposium led to the publication of a collection of essays (Glick Schiller, Basch and Blanc-Szanton 1992). 
By developing a more coherent theoretical framework and a common analytic vocabulary for understanding transnational processes, the conference sought to bring a global and comparative perspective to the study of transnational flows of populations and cultural productions at the level of the nationstate. A main concern was to explore how transnational flows of people and ideas seemed to problematize national borders and processes of class reproduction, while maintaining hierarchies of domination between and within states.

Twelve years later, as part of the ongoing critical reassessments, misuses as well as refinements of the transnational perspective on migration, Ayşe Çağlar and Nina Glick Schiller organized the 2006 Max Planck workshop "Migration and city scale" as a dialogue between students of migration and urban geographers. ${ }^{4}$ This reevaluation stimulated analyses of migrants in cities (Çağlar y Glick Schiller 2006, 2011; Feldman-Bianco 2011, 2012). Considering the interpenetration of differing geographical scales, this paradigm studies immigrants as active protagonists of the social fabric of the cities in which they live, as well as of their local and transnational practices in specific historical conjunctures, times and places. By bringing to light the relations between migrants, transmigration and the restructuring of global capitalism, this reassessment allows us to reveal immigrants' agency and their roles in the global processes that restructure specific cities. It also allowed explaining the reconstruction processes of the global, the national and the local through unequal networks of relations in specific times and places.

Since its publication, Nations Unbound has been exposed to intense scrutiny and transnational studies on migration have proliferated. ${ }^{5}$ In my own rereading of the book today, I criticize a certain methodological nationalism, and a predominant focus on the transnational actions and strategies of transmigrant leaders in their relations with the homeland, at the expense of a more detailed ethnography of the everyday lives of migrants and the transnational roles they play in the cities where they have settled. Nevertheless, it is worthwhile to consider that in the 1980s and 1990s, fieldwork on immigration led us to investigate the ongoing redefinitions and roles of the nation-states. ${ }^{6}$ Because

4 See Kearney (1995); Smith and Guarnizo (1998); Faist (2000); Al-Ali, Black and Koser (2001), Guarnizo, Portes and Haller (2003); Kivisto (2001); Wimmer and Glick Schiller (2002); Pessar and Mahler (2003); Levitt and Glick Schiller (2004); Vertovec (2009), among others.

5 It is not the purpose of the paper to review the vast and heterogeneous literature on transnational migration and its different perspectives. The reader is referred, for instance, to Kearney (1995); Pessar and Mahler (2003); Levitt and Glick Schiller (2004); Vertovec (2009); Dahinden (2017).

6 This focus on the state and nation was central to various panel discussions organized by Glick Schiller, Basch and Szanton-Blanc, such as "Deterritorialized nations, diasporas and new imagined communities: the global context," in 1991; "Citizenship, culture and class: new transnational spaces and deterritorialized or reterritorialized nation-state building," in 1994; and "Transmigrants, [continues] 
of this major concern, in the 1990s, in a conjuncture of intense debates about the disappearance of nation-states, the transnational paradigm allowed me to shift the emphasis to the reconfigurations of nation-states and their national narratives against the restructuring of global capitalism and changing modes of governability (Feldman-Bianco 1995). Therefore, it remains crucial to differentiate between the critique of and the need to discard methodological nationalism and the validity of research on nation-state reconfigurations and roles, including state violence, considering the changing global political economy. As I shall demonstrate, based on my own fieldwork and ethnographies, the nationstate continues to be an important actor on issues related to migration and displacements. At the same time, there are global trends interrelating migration and displacements, racialization, colonialism, capitalism and its structures of domination that cut across and reconfigure the role of nation-states.

\section{NATION-STATE, TRANSNATIONALISM AND TRANSMIGRATION: CRITICAL DIALOGUES AND REASSESSMENTS FROM THE VIEWPOINT OF AN ETHNO-HISTORICAL COMPARATIVE RESEARCH PROJECT}

Since the 1990 New York Academy of Sciences symposium, my comparative research projects have been in dialogue with the ongoing theoretical debate on how to frame analyses of transnational migration. These dialogues reveal the value of ethno-historical examinations for exposing social complexities, continuities and changes and for indicating that synchronic "research findings" may capture only a particular moment of ongoing social processes.

Differently from most scholars who in the 1980s and 1990s examined the national projects of former colonies, I focused on a secular transmigration from towns and rural areas of Portugal (a former imperial metropolis) to New Bedford, Massachusetts and neighboring New England towns. While new immigrants from the Caribbean and South Asia were replacing earlier European migratory contingents, the continuous renewal of Portuguese immigration to New England allowed for a close examination of patterns of continuity and change. In a first phase, the ethnographic present led me to decipher the meanings of the multiple Portuguese temporalities and spatialities inscribed in the city. From that viewpoint, I examined both the incorporation and exclusionary processes of migrants in New Bedford and Portugal and the construction of social fields and networks of unequal relations that link localities of origin and settlement in different times. Thereby, I suggested that in both the past and the present, Portuguese migrants simultaneously created ethnic enclaves in New England and maintained connections with their communities 
of origin. Yet, in that ethnographic present of the late 1980s, there was an intensification of transnational practices and connections, and a simultaneous exacerbation of localisms by the Portuguese as an ethnic enclave in the city. These seemingly contradictory patterns anticipated the dynamic interplay between globalization and localisms that distinguishes this juncture of global capitalism. ${ }^{7}$

Portugal itself offered an interesting case study, given that it was an imperial (albeit subaltern) metropolis and, at the same time, a nation of emigrants. However, from my location in the city of New Bedford, I could offer insight only into one dimension of the reconfiguration of the Portuguese postcolonial nation - the incorporation of Portuguese emigrants into a nation that is based on population rather than territory. For this reason, I suggested that the incorporation of the Portuguese diaspora into the Portuguese postcolonial global nation had replaced the former overseas colonies in the spatial (re)imagining of the former space of the empire.

Subsequently, my participation in the 1994 Wenner-Gren symposium on "Transnationalism, nation-state building, and culture" challenged me to pay attention to the particularities of Portugal's efforts to redefine itself as a global nation and, thus, contribute to a global perspective on migration. I compared my early New Bedford research data with preliminary fieldwork conducted in Lisbon, Portugal and São Paulo, Brazil. This comparative viewpoint enabled me to expose the reconfigurations of a former colonial metropolis into a postcolonial nation that became a member of the European Community. I demonstrated that the incorporation of Portuguese transnational migrants into the nation and the transformation of Portugal into a destination for immigrants from its former colonies were two interconnected facets of the complex processes of the redefinition of the Portuguese nation in the postcolonial era. On these grounds, I indicated that, in response to the restructuring of global capital and the formation of regional economic blocks, former European empires have tended to redesign postcolonial nations to favor bonds of descent and race and, therefore, the "rights to roots" - thus enabling their (communitarian) citizens to circulate freely within the European economic communitarian space. Yet, since the Schengen era, in view of increasing controls over national territorial borders and the entry of non-communitarian citizens, including those from former colonies, there has been a simultaneous and interrelated process of reterritorialization into the "European fortress." Thus, rather than examining just the formation of deterritorialized nations, I affirmed that it was necessary to consider the politics of deterritorialization and reterritorialization in the refurnishing of the nation-states, as well as their unequal (scalar) locations and relations within the larger political economy (Feldman-Bianco 1995). 
Towards this end, as I sought to further compare the reversed transmigrations between Brazil and Portugal, I combined the transnational perspective on migration with Santos' (1995) position on the need to consider Portugal's semi-peripheral position in the wider economy, to scrutinize its alleged lack of differentiation from former colonies, particularly in relation to Brazil. This comparison led me to questions about colonialism and postcolonialism and to a broader, global, perspective on migration - which considers not only the movements of people, but also of symbols, goods and capital. ${ }^{8}$ From that conceptual reassessment, I also engaged in dialogues with students of the so-called postcolonial moment, who have tended to examine yet another dimension of the national redefinition process - the presence of immigrants from former colonies in the ex-imperial metropolis. Given their interests in the supplementary narrations of the nation (Bhabha 1994) and in building histories that challenge the constructed homogeneities (C. Hall 1996), they have emphasized the cultural production of difference.

Since the interdependencies between the former imperial metropolis and various colonial sites have specific histories, positions and relations of power, I focused attention on the specific interdependencies and mutual constitution between Portugal and Brazil and their shifting locations (or rescaling) in the wider political scene. While scholars such as Stuart Hall (1996) and Homi Bhabha (1994) focused attention solely on the cultural construction of difference, it became imperative, in view of the continuous production of ambiguous cultural borders between Portugal and Brazil, to scrutinize the production of sameness, as well as of difference, between the two semi-peripheral countries. Thus, my analysis depicted the construction of homogeneity, that is, of hegemony and colonial continuities in postcolonial times. It further emphasized the need to consider the positioning and, thus, rescaling of the nation-states in the global political economy.

I hence analyzed the development of national policies and elite discourses regarding the hegemonic constructions of national belonging in both nations. Thereby, I attempted to decipher the interstices and intricacies underlying power, domination, subordination and inclusion, by examining the power relations between the former imperial metropolis and what had been its major colony, in the context of the multiple and differential movements of people, symbols, products and capital. By placing these comparative case studies within the broader scenery of global capitalism, I juxtaposed policies, politics, movements, restriction of movements, and events concerning immigration and emigration to untangle the complexities underlying the relationships

8 My Portuguese-Brazilian conversations with anthropologists and historians who were studying different aspects of the Portuguese Empire were most valuable for my conceptual reassessments (see Bastos, Almeida and Feldman-Bianco 2002). 
among transnationalism, transmigrant "diasporas" and processes of national redefinition in this era of contemporary globalization. Above all, I attempted to combine questions on transmigrant "diasporas" with questions on Empire and postcolonialism as part of the same problem under study in an ethnography of the Portuguese state. ${ }^{9}$ This in-depth analysis has enabled me to examine both the immigration and emigration policies of the Portuguese postcolonial state as constitutive of the ways in which government officials have negotiated Portugal's position in the global economy. Moreover, it allowed me to disclose the reconstitution of ideologies of Empire in the new political configurations in that conjuncture of global capitalism (Feldman-Bianco 2001).

This comparison included the Portuguese of New Bedford, where I have continued to conduct intermittent research. Informed by my triangular comparative perspective on Portugal's evolving sense of nation and the ongoing transnational practices in its diaspora, I responded to Çağlar and Glick Schiller's call to study migrants and city scale. I examined the continuities and changes in the positioning and roles played by Portuguese migrants and their local and transnational practices considering the repositioning of both New Bedford and Portugal in the global political economy. Instead of adopting the ethnic group as my unit of analysis, I focused my attention on New Bedford and local politics to explain the relations among globalization, city scale and the incorporation of migrants. By interrelating local and global processes, I showed how the incorporation of these migrants to New Bedford has enmeshed with their incorporation in Portugal and, by extension, the European Union. From this perspective, I exposed the apparent paradoxes that permeate the ongoing neoliberal projects that are grounded on the flexible organization of labor, restrictive immigration policies justified by national security that criminalize immigrants, as well as ideologies of cultural diversity. ${ }^{10}$

The two respective dimensions of my comparative project - the ethnography of the Portuguese state and the social history of New Bedford - intersected. In the process, I related the agency of the immigrants to the political economy, to expose the dynamic relations between the local, the national and the global. Through the lenses of immigration, the social history of New Bedford exposes the history of capitalism and the increasing inequality in the world we live in, which is characterized by intense social and ecological displacements, expulsions, brutality ${ }^{11}$ and precarious lives in a conjuncture marked by accumulation through dispossession. ${ }^{12}$

9 See, for instance, Feldman-Bianco (2001, 2010b); Bastos, Almeida and Feldman-Bianco (2002).

10 See Feldman-Bianco $(2011,2012)$.

11 See Sassen (2014).

12 See Butler (2004); Butler and Athanasiou (2013). 


\section{TOWARDS THE ELABORATION OF A GLOBAL PERSPECTIVE}

\section{ON DISPLACEMENTS}

My research findings, coupled with my experience presiding the Brazilian Anthropological Association (ABA) in 2011-2012, made me aware of the need for a broader notion of migration and displacements to understand and conceptualize the varieties, scale and spaces of mobilities, including restrictions to and limitations on mobilities. ${ }^{13}$ Following the ABA's tradition of combining academic scholarship and social action, we confronted and took action against the violation of the human, territorial and environmental rights of indigenous and other traditional populations caused by large development projects such as the Belo Monte hydroelectric dam in the Amazon. At the same time, political alliances between agribusiness and evangelical leaders have systematically sought to prevent the demarcation of indigenous lands. Tensions between agribusiness and the traditional populations over their original territories have been chronic. In the process, indigenous leaders, particularly those of the Guarani-Kaiowás, have been murdered and others threatened. Furthermore, there have been many urban displacements and "cleansing" processes prompted by real estate interests, particularly related to the 2014 soccer World Cup and 2016 Olympics, which also demand the attention of anthropologists. Meanwhile, simultaneously to attempts to formulate a new immigration law focusing on human rights, human trafficking campaigns - which have criminalized immigration strategies - became an important theme for the Brazilian government and the Catholic church. More recently, in accordance with the current "war against terror," Brazil has approved a new antiterrorism act, which resulted in a National Borders Security Strategy as part of the Borders Strategic Plan.

In this context, I began to notice that these various forms, scales and spaces of displacements seem to reveal a new logic and similar patterns of expulsion (Sassen 2014), which is amplifying social inequalities and creating new contingents of the dispossessed in this conjuncture of global capitalism.

13 In fact, given my concern for the movements of people, signs, products and capital, a research line entitled "Space and power" was included in the research program "Identities: reconfigurations of culture and politics" that I directed at CEMI (1997-2004/Ministry of Science and Technology/Pronex). This research line, coordinated by Antonio Augusto Arantes, centered on the transdisciplinary study of the transformations of public space as a place of politics and memory. Special attention was given to cities and sites designated as part of the Brazilian or world cultural heritage. The case studies examined by this program focused on the politics of identity and the formation of particular space-time configurations in Brazil and Portugal, in the context of contemporary social experience. In addition, within the realm of the Clacso Working Group "Migración, cultura y política," we have discussed the need to examine different movements and restrictions to movements such as transnational migration, internal political displacements (such as the Colombian desplazados politicos) and refugees as part of the same problems of study. 
Simultaneously to the predominance of multiculturalist ideologies and rhetoric based on human rights and humanitarianism, there has been a cumulative production of social categories and a technocratic governance of securitization, criminalization and dehumanization of poverty that transcend national states.

Moreover, at the same time that movements of capital, signs and virtual communication seem to dissolve borders, certain flows of people, products and places have been the focus of restrictive policies and selective control. Thus, issues related to transnational migrants, refugees and asylum seekers have become central to the agendas of national governments and multilateral agencies. In the same manner, internal displacements, resulting from the removal of territories or people at the margin, have been at the heart of both local and national policies, echoing global multilateral agendas.

Understanding these processes and apparent paradoxes demands new theoretical paradigms that can dissolve the ingrained positivist fragmentation that divides knowledge in different fields of study and reifies the nation-state. In taking on such a challenge, I suggest the adoption of a global perspective on migration and displacements for the analysis and theorization of the various types, scales and spaces of mobilities and immobilities, one that considers the interstices of domination and power and the production of inequalities as inherent to the restructuring of global capitalism (Feldman-Bianco 2015). Whether we are looking at transnational migration, political and environmental refugee seekers, human trafficking or the removal of populations and or territories due to large development projects or real estate interests, or assassinations and the militarization of urban peripheries, the idea is to investigate how mobilities and immobilities of many types reflect the production of social inequalities in global capitalism today. This implies considering migrations, migration policies and the social agency of migrants, refugees and other (domestically) displaced people - such as indigenous populations, squatters, families whose children were assassinated or incarcerated - in a global scenery marked by flexible capital and labor, outsourcing, privatization, financialization, technocratic governance, state redistribution and state violence. This conceptual tool allows discerning mobilities and immobilities and the production of inequalities as part of the dynamic formation of capital, which is simultaneously global, national and specifically local. ${ }^{14}$

14 To develop such a conceptual tool, I have organized and co-organized a series of symposiums and panels inviting colleagues from Australia, Europe, Latin America and North America. Each was asked to examine, based on their ethnographic research and theoretical explorations on local and global processes, the spatial, temporal, gender, class or racial aspects of displacements and inequalities, considering developmental and/or neoliberal policies. Whether considering transnational migrations, political and environmental refugee seekers, human trafficking or removals of populations from their [continues] 
This perspective necessarily demands global ethno-historical analyses capable of revealing current social continuities and ruptures. While human mobility is millenary, ever since the $15^{\text {th }}$ century the movement of people around the world has been part of capital formation and thus enmeshed with racialization, colonialism, capitalist expansion and corollary structures of domination and inequalities. The $15^{\text {th }}$ and $16^{\text {th }}$ centuries evoke the era of navigation and exploration along with the transcontinental trafficking of African slaves and the invention of racialization - first of the negro and the indio and later also of a free migrant labor force. The $18^{\text {th }}$ century saw the formation of nationstates and the screening of who could enter (or leave) national borders. Racialized foreignness and otherness have been immanent threats as they bring to the fore questions of citizenship and the relations between the state and the nation (Bourdieu 2004). Britain's decision to withdraw from the European Union and Trump's victory for the presidency of the United States bring to light deep-rooted xenophobic nationalisms that reject and criminalize immigration. Classifications and gendered racialization of immigrants and other subaltern populations have been embedded in structural and state violence, both in the past and in the present.

There is, hence, an inseparability between migration and displacements, racialization, colonialism and capitalism and its structures of domination that go beyond the nation-state. In this sense, it is helpful to consider Quijano's coloniality of power construct, which is "grounded on the imposition of a racial and ethnic classification of the world's population affecting the material and subjective facets of social existence" (Quijano 2000: 345). From this stance, a global perspective on migration and displacements further requires theorizing the intersectionalities of race, racism, racialization and gender since this perspective concerns a diverse set of actors, including indigenous people, Afro-descendants, immigrants, refugees or squatters among other categories that tend to be studied separately. ${ }^{15}$ Conversely, there are immigrants and refugees who are Africans, Afro-descendants or Indigenous people and urban squatters. Considering the social agency of

settlement territories, the idea was to investigate how mobilities of many kinds have been tied to producing inequalities in the current conjuncture of global capitalism.

15 Escalating discrimination and xenophobia in this conjuncture of global capitalism calls for a broader theorization of race and racism far beyond the ongoing anthropological debates centering solely on either the diasporic descendants of African slaves, indigenous populations or immigrants, refugees and other displaced people. Influenced by Quijano's "coloniality of power," there have been attempts to develop an encompassing theory of race and racism in the Americas by embracing both black and indigenous people who suffer from somewhat similar colonial constructions of racial subordination. Yet, at the same that new and old forms of racism against these populations persist, contingents of immigrants, refugees and other displaced people around the world have been increasingly exposed to criminalization, securitization and racial subordination, widening even more the theorization on race and inequality as part of the logic of global capitalism. 
these multiple protagonists, it is crucial to examine their actions, reactions, inactions, strategies and social mobilizations regarding the prevailing ambiguities between differential access and exclusion to human and citizenship rights. Consequently, this approach demands an investigation of the intrinsic relationships among the agency of migrants and refugees and other displaced people and displacements, inequalities, securitization, militarization, national reconfigurations, structural state violence and dispossession through times and places. From this viewpoint, this broader notion of migrations and displacements has the conditions to lay the comparative bases for a better comprehension of the new and old logics of social exclusion produced by contemporary capitalism.

Sassen (2014) and Harvey (2005) help us to understand the present global conjuncture from the viewpoint of capital. As Sassen (2014: 1) signaled, the policies and practices of the past two decades have led to a new logic of expulsion that is indicated by a sharp growth in the numbers of people, enterprises and places expelled from the core of the social and economic order. In this context, she deploys the notion of expulsion to move beyond the idea of growing inequalities and capture the pathologies of today's global capitalism. Harvey (2005), meanwhile, formulated the concept of accumulation by dispossession to explain the central role played by dispossession in neoliberal modernity. His analysis, which focuses on the United States and Europe, points to the emergence of a new imperialism nourished by spatial and temporal displacements that spark accumulation by dispossession to open new markets through an international neoliberal policy of privatizations and the pressure exercised by global organizations, such as the International Monetary Fund. These policies, and ensuing super-accumulations of capital that have caused periodical crises of predatory devaluation of assets in various parts of the world, are at the heart of contemporary capitalism.

Economic depressions, such as those that took place in Latin America in the 1980 and 1990s, as well as the 2008-2009 great recession in Europe and the US, express ways to address chronic problems of super-accumulation of capital. These recessions disrupt people's lives, causing migrations, refugees from wars, expulsions from the countryside due to large development projects or from cities because of real estate speculation, among other displacements. If the economic recession of the 1980s and 1990s directed migrants from former colonies to ex-European metropoles and the United States, the 2008-2009 recession in central nations resulted in a reverse movement - from Europe to the former colonies. In addition to an intensification of interregional migration, there has been, particularly because of the limited growth in Europe and North America and the strict migratory policies, an increase in South-South transcontinental migrations. 
The European Union's restrictions on the circulation of people began to expand in the late 1980s, under the Schengen Treaty that differentiated between communitarian and extra-communitarian citizens. Extra-communitarians were also distinguished by binary categories: "legal" or "regular" (documented migrants who had the right to enter and circulate within the EU and to access its intercultural policies) and "illegal" or "irregular" (migrants without proper documentation and without the right to enter the European communitarian space). In the United States, historically a nation of immigrants whose laws oscillated between the opening and closing of the immigration gates according to economic fluctuations, the association between migrants and terrorism began in 1996 with the Oklahoma bombing and intensified after September 11, 2001 with the so-called "war against terror." While national migratory legislation has historically differentiated between "desirable" and "undesirable" migrants, since the 1990s there has been, particularly in central nations, a prevailing equation linking migration, terrorism and human trafficking, thus legitimizing the production of illegality entrenched in the currently draconian policies. Even refugees who were able to escape wars at home have confronted ongoing criminalization and recurrent discrimination and xenophobia. Because of the growing surveillance at borders, women, men and children have been arrested, confined in detention camps or deported, while risking their lives crossing borders, either to escape from violent conflicts in their homelands or just to fulfill their dreams, hopes and projects of a better life. Many die, sometimes brutally murdered during these passages. Borders, transformed into battlefields, dramatically symbolized by security walls, have become metaphors for a hopeless globalization.

These restrictive policies are now a constituent part of the juridicalization of migrations (Dias 2014; Domenech 2015). Multilateral agendas have produced and exported new categories, such as "human trafficking," "smuggling of immigrants," "illegal immigrants" and "terrorism," sometimes through bilateral cooperation with countries of the South. Together with a regionalization of migratory policies linked to the constitution of a global regime of control over transnational migrations, technocratic regulatory policies have engendered new forms for the organization and classification of migratory flows, which have also been adopted by Latin-American nations. The old categories and classifications of the "undesirables" were subsumed under the "new threats" established by the international community, such as drug trafficking, terrorism, trafficking in persons and undocumented migration (Domenech 2015).

According to Domenech (2015), today's deportations have become a substantive part of a regime of migration control that articulates (and does not separate) "securitization" and humanitarianism. Moreover, besides its 
insufficiency, humanitarianism treats migrants and refugees as passive "victims." Thus, different forms of expulsion (border rejection, discarding, assisted and voluntary returns) have become part of strategies to combat the new undesirables: precisely those immigrants considered by technocratic dogma, potential threats that do not even offer advantages for order and which are therefore disposable.

However, these policies of control and discipline are not restricted to transnational migrants. They are also directed at the urban populations of the favelas and peripheries of large cities, as well as indigenous and other traditional populations. Gabriel Feltran (2016), for example, points out that until the 1970s, residents of the São Paulo peripheries and favelas were classified as "workers," while today they are considered "criminals" and "marginal" by the globally exported urban policies. Control policies and even killings in Rio de Janeiro and São Paulo follow these global standards. Therefore, the paradigm of securitization is more embracing in these times of accumulation by dispossession as the cases of Peacemaking Police Units (UPP) showed. Militarized violence generates more violence.

Taking into account the current conservative turn in various parts of the globe, these policies are stirring up racism and xenophobia against immigrants, refugees, indigenous people, blacks, poor urban squatters, homosexuals, among other people at the margins. But at the same time, this state of affairs is leading to the formation of social movements composed of different segments of civil society (women, blacks, church, trade unionists, immigrants and refugees).

Consequently, it is essential to examine how social categories are formulated within the realm of power relations, including their meanings in specific situations and circumstances. We need to consider that categories such as "migration-immigrants," "legal-illegal" or "regular-irregular," "deported-deportation," "human trafficking," "trafficking of illicit goods," "refugee-refugees," "squatters," "missing persons," "state violence," "internal enemies," "public security," "human rights," "victim-accuser," "foreigner," "indigenous," "Afro-descendent," among others, as well as various stereotypes, are social constructions loaded with differential meanings. These social constructions express processes of insertion and exclusion of different protagonists. As a contraposition to the current production of illegality and criminalization, social movements construct their own categories by demanding "a world without borders," "universal citizenship," and "complete equal rights for immigrants," who as "human beings are not illegal." Thus, it is essential to examine how these categories are set in motion, when and by whom, as well as their differential meanings in specific contexts, such as in migratory laws, administrative and court actions or social mobilizations, considering the social processes and from the viewpoint of a history in the making (Thompson 1963). In this man- 
ner, we will be able to discern the interstices of capitalism, domination and the production of inequalities.

Migrations are complex phenomena that present multiple faces and bring to light cultural differences, as well as the intersectionalities of class, race, gender, generation and regions. It is also undeniable that migrants and other displaced people reconstruct their knowledges and experiences and that their displacements tend to be central to their families' transnational projects in the localities that they left, while they simultaneously become part of the places where they relocate. In the past, migratory laws considered migrants of "yellow" and "black" skin who belonged to certain nationalities to be "undesirable." In those times, when class movements were central to immigrant mobilizations, the targets of deportation were anarchists and communists, many of whom were active in labor struggles for better working conditions. Today, the deported are undocumented migrants who belong to "disposable" subaltern populations, such as indigenous peoples, Afro-descendants, urban squatters and settlers of the periphery who have experienced various forms of displacement. In a conjuncture of escalating racism, xenophobia and criminalization of poverty, we are witnessing the undermining of labor rights by neoliberal policies, flexible labor and outsourcing. Multicultural ideologies and identity politics have made way for new forms of social mobilizations of identity and, more recently, post identities. Understanding the fragmentation of these social movements as well as the situations in which different mobilizations come together at the grassroots is also a constituent part of the global perspective of migrations and displacements.

\section{FINAL CONSIDERATIONS}

Anthropology as a praxis opens new horizons in this way, new ideas and paradigms tend to be a product of ethnographic research conducted in specific times and places. Thus, theoretical and methodological assessments are continuously subjected to critical dialogues, reassessments, and refinements. Since I related the transnational perspective on migration to my own comparative research project experiences, I was able to contextualize the historical conjuncture that led to the formulation of this paradigm as well as the potential of ethnography as a tool for the renewal of our ideas.

As we have seen, the transnational perspective on migration was an outcome of fieldwork conducted in the United States in the late 1980s, mostly among immigrants from former colonies. This was a time marked by both the renewal of the migratory contingents settling in American cities and the reconfiguration of nations and nationalisms. This combination of factors highlighted the transnational character of immigrants' social fields and their simultaneous lives - between places of origin and settlement. By placing 
migration, migration regimes and national reconfigurations against the ongoing restructuring of the global political economy and unequal power relations, this paradigm renewed our ideas and concepts on migration. Thus, it challenged the former predominant characterization of immigrants as uprooted people whose social organization, work and culture tended to be studied solely from the standpoint of their lives in their countries of destination. As my ethno-historical research indicated, this limited perspective together with the (then) prevailing "melting pot" ideologies prevented scholars from noticing immigrants' continuing - even if weakened - social fields, which linked their homelands and localities of settlement into a single construction (Feldman-Bianco 1992).

Differently from my interlocutors, I studied migrants from a former imperial metropolis. My ethno-historical comparative research thus required me to combine the transnational perspective on migration with Santos' (1995) position on the need to consider Portugal's semi-peripheral location in the wider economy, to scrutinize its alleged lack of differentiation from former colonies, particularly Brazil. This comparison led me to questions about colonialism and postcolonialism and to a broader, global perspective on migration, which considers not only the movements of people, but also of symbols, goods and capital. This conceptual reassessment, together with the dynamics of deterritorialization and reterritorialization in the reconfiguration of the Portuguese postcolonial nation, enabled me to unite questions of transnational migration and questions of Empire and postcolonialism as part of the same research problem. From the perspective of an ethnography of the Portuguese state, I discovered the reconstitution of ideologies of Empire in the new political configurations of postcolonial times and showed how both immigration and emigration policies were central to the ways in which government officers negotiated Portugal's position as a member of the EU in the global political economy.

During fieldwork in New Bedford in the late 1980s, I was only able to offer insight into one dimension of the reconfiguration of the Portuguese postcolonial nation - the incorporation of Portuguese emigrants into a "deterritorialized" nation that is based on population rather than territory. Nevertheless, when I focused on the former Portuguese metropolis and began a comparative transnational study between Lisbon and São Paulo, I identified concomitant and interrelated processes of escalating reterritorialization because since Schengen it has been increasingly difficult for non-communitarian citizens to enter and circulate within the "European fortress." These interrelated processes of deterritorialization (of emigrants) and reterritorialization (of immigrants) have become predominant in the refurnishing of nation-states and nationalisms as a direct response to the restructuring of global capitalism. 
In a conjuncture marked by new nationalisms, the transnational perspective on migrations encouraged researchers to conduct fieldwork prioritizing the relations between migrants and their homeland and long-distance nationalism. However, in the 1980s and 1990s, a period of increasing influx of immigrants to European cities, and the corollary issues of "integration," Çağlar and Glick Schiller's (2011) reassessments called for the study of migrants and city scale. In a conjuncture marked by the interpenetration of different geographic scales, these conceptual refinements allowed us to study transnational migrants as active protagonists of the social fabric of the localities of settlement and their local and transnational practices. It also enabled us to discern their agency in the global processes that restructure cities, and to explain the construction of the global, the national and the local through unequal networks of relations.

As we have seen, informed by my comparative ethno-historical research findings, I focused on a social history of New Bedford through the lenses of immigration to explain the relations among globalization, city scale and the incorporation of migrants. By interrelating local and global processes and focusing on immigrants and their agency, I showed how their incorporation in New Bedford has enmeshed with their incorporation in Portugal and, by extension, the European Union. From this perspective, I exposed the apparent paradoxes that permeate the ongoing neoliberal projects that are based on undermining historic achievements of labor movements, the flexible organization of labor, restrictive immigration policies justified by national security that criminalizes immigrants, as well as ideologies of cultural diversity in a conjuncture marked by accumulation through dispossession.

The ongoing social processes of increasing securitization, exploitation and dispossession made me aware of the need for a global perspective on migration and displacements to comprehend and conceptualize the varieties, scales and spaces of mobilities and the restrictions and limitation to these mobilities, in this juncture of capitalism. This paradigm, as a gateway to understanding and exposing social continuities and ruptures, is part of my recurrent attempts to discern social processes beyond the prevailing positivism that divides knowledge into different fields of study and tends to reify the nation-state. While the notions of "expulsions" and "accumulation by dispossession" were developed from the viewpoint of capital, the global perspective on migration and displacements aims at uncovering the interstices of domination and power, and the production of inequalities inherent to the restructuring of global capitalism. Accordingly, it requires that we contextualize migrations, migratory policies and the role of migrants and refugees, as well as the internal displacements of subaltern populations - indigenous people, quilombolas, squatters, families of executed or imprisoned children in a world scenario marked by flexible capital and 
labor, privatization, financialization, technocratic governance, state redistribution, and state violence.

Furthermore, as I have already outlined, this global migration and displacements notion demands:

- global ethno-historical analyses and theorization regarding the intersectionalities of race, racism, racialization, gender and class;

- investigation of the intrinsic relationships among the agency of migrants and refugees and other displaced people and displacements, inequalities, securitization, militarization, national reconfigurations, structural state violence and dispossession through times and places;

- examination on how social categories are formulated and set in motion, when and by whom, within the realm of power relations, as well as their differential meanings in specific contexts, such as in migratory laws, administrative and court actions or social mobilizations.

In a conjuncture of escalating racism, xenophobia, criminalization of poverty and increasing polarization between the conservative right and democratic forces, it becomes imperative to uncover potential "emancipatory spaces" in order to "reinvent democracy" (Santos 2016). Therefore, it is not by chance that examining the social movements of transnational migrants for their rights, at the local level, as well as their articulations with the national, transnational and global, is also part of the global perspective on migration and displacements. It is equally important to explain the fragmentation of these social movements as well as the situations in which different protagonists come together at the grassroots level and, at least situationally, these movements turn into "emancipatory spaces." 


\section{REFERENCES}

AL-ALI, Nadje, Richard BLACK, and Kahlidk KOSER, 2001, "The limits to transnationalism: Bosnian and Eritrean refugees in Europe as emerging transnational communities", Journal of Ethnic and Migration Studies, 24 (4): 578-600.

BASCH, Linda, Nina GLICK SCHILLER, and Cristina SZANTON BLANC, 1994, Nations Unbound: Transnational Projects, Postcolonial Predicaments, and Deterritorialized Nation-States. S.1., Gordon and Breach Science Publishers.

BASTOS, Cristiana, Miguel Vale de ALMEIDA, and Bela FELDMAN-BIANCO (eds.), 2002, Trânsitos Coloniais: Diálogos Críticos Luso-Brasileiros. Lisbon, Imprensa de Ciências Sociais.

BHABHA, Homi K., 1994, The Location of Culture. New York, Routledge.

BOURDIEU, Pierre, 2004, "Preface", in Abdelmalek Sayad, The Suffering of the Immigrant. Cambridge, Polity Press, xi-xiv.

BUTLER, Judith, 2004, Precarious Life: The Powers of Mourning and Violence. London and New York, Verso.

BUTLER, Judith, and Athena ATHANASIOU, 2013, Dispossession: The Performative in the Political. Cambridge, Polity Press.

ÇAĞLAR, Ayşe, and Nina GLICK SCHILLER, 2006, "Migrant incorporation and city scale: theory in the balance", Halle/Saale, Max Planck Institute for Social Anthropology, mimeo.

ÇAĞLAR, Ayşe, and Nina GLICK SCHILLER (eds.), 201 1, Locating Migration: Migrants and Cities. Ithaca, Cornell University Press.

COMAROFF, John, 2010, "The end of anthropology, again: on the future of an in/discipline”, American Anthropologist, 112 (4): 524-538.

DAHINDEN, Janine, 2017, “Transnationalism reloaded: the historical trajectory of a concept", Ethnic and Racial Studies, 40 (9): 1474-1485.

DIAS, Guilherme Mansur, 2014, "Migração, segurança e governabilidade migratória: o papel dos organismos internacionais”, Revista Crítica y Emancipación, 11: 557-580.

DOMENECH, Eduardo, 2015, "Controle da imigração indesejável: expulsão e expulsabilidade na América do Sul", Ciência e Cultura, 67 (2): 25-29.

FAIST, Thomas, 2000, “Trasnationalization in international migration: implications for the study of citizenship and culture", Ethnic and Racial Studies, 23 (2): 189-222.

FELDMAN-BIANCO, Bela, 1992, "Multiple layers of time and space: the construction of class, ethnicity and nationalism among Portuguese immigrants", in Annals of the New York Academy of Sciences, 645 (1): 145-174.

FELDMAN-BIANCO, Bela, 1995, "The state, saudade and the dialectics of deterritorialization and reterritorialization", working paper, Oficina do CES, n. ${ }^{\circ} 46$.

FELDMAN-BIANCO, Bela, 2001, "Brazilians in Portugal, Portuguese in Brazil: constructions of sameness and difference", Identities, 8 (4): 607-650.

FELDMAN-BIANCO, Bela, 2010a, "Migración, enfrentamientos culturales y reconstrucciones de la identidad femenina: el caso de las intermediarias culturales portuguesas", in Stefanie Kron et al. (eds.), Diasporische Bewegungen im transatlantischen Raum (Diasporic Movements - Movimientos Diaspóricos). Berlin, Tranvía, 25-49.

FELDMAN-BIANCO, Bela (ed.), 2010b, Nações e Diásporas: Estudos Comparativos entre Brasil e Portugal. Campinas, Editora Unicamp. 
FELDMAN-BIANCO, Bela, 2011, "Remaking locality: uneaven globalization and unequal incorporation of transmigrants", in Ayşe Çağlar and Nina Glick Schiller (eds.), Locating Migration: Migrants and Cities. Ithaca, Cornell University Press, 213-234.

FELDMAN-BIANCO, Bela, 2012, "The aftermath of a rape case: the politics of migrants' unequal incorporation in neoliberal times", in Pauline Gardiner Barber and Winnie Lem (eds.), Migration in the $21^{\text {st }}$ Century: Political Economy and Ethnography. New York and London, Routledge, 175-195.

FELDMAN-BIANCO, Bela, 2015, "Apresentação: deslocamentos, desigualdades e violência do Estado", Ciência e Cultura, 67 (2): 20-24.

FELDMAN-BIANCO, Bela, and Nina GLICK SCHILLER, 2011, "Una conversación sobre transformaciones de la sociedad, migración transnacional y trayectorias de vida”, Crítica y Emancipación, 5: 9-42, available at < http://biblioteca.clacso.edu.ar/clacso/se/20120 229121218/CyE5.pdf > (last access in February 2018).

FELDMAN-BIANCO, Bela, et al. (eds.), 201 1, La Construcción Social del Sujeto Migrante en América Latina: Prácticas, Representaciones y Categorias. Quito, Flacso, Clacso y Universidad Alberto Hurtado, 235-280.

FELTRAN, Gabriel di Santis, 2016, “Entre ‘trabajadores' y 'bandidos': cuatro décadas de desplazamientos del conflicto urbano en los márgenes urbanos de Brasil (1970-2010)”, in F. Besserer (ed.), Intersecciones Urbanas: Ciudad Transnacional/Ciudad Global. Mexico, DF, Juan Pablos Editor, 221-256.

GLICK SCHILLER, Nina, 2014, "Twenty years of the transnational migration paradigm: conjuncture, temporality, and agency", Annual Meeting of the American Anthropological Association, Washington, DC, December 2-7, mimeo.

GLICK SCHILLER, Nina, Linda BASCH and Cristina BLANC-SZANTON (eds.), 1992, special issue "Towards a transnational perspective on migration: race, class, ethnicity and nationalism reconsidered", Annals of the New York Academy of Sciences, 645 (1).

GUARNIZO, Luis E., Alejandro PORTES, and William HALLER, 2003, "Assimilation and transnationalism: determinants of transnational political action among contemporary migrants". American Journal of Sociology, 108 (6): 1211-1248.

HALL, Catherine, 1996, "Histories, empires and the postcolonial moment", in Iain Chambers y Lidia Curti (eds.), The Postcolonial Question: Common Skies, Divided Horizons. London, Routledge, 65-77.

HALL, Stuart, 1996, "Identidade cultural e diáspora", Cidadania: Revista do Patrimônio Histórico e Artístico Nacional, 24: 68-76.

HARVEY, David, 2005, A Brief History of Neoliberalism. Oxford, Oxford University Press.

KEARNEY, Michael, 1995, "The local and the global: the anthropology of globalization and transnationalism”, Annual Review of Anthropology, 24: 547-565.

KIVISTO, Peter, 2001, “Theorizing transnational immigration: a critical review of current efforts", Ethnic and Racial Studies, 24 (4): 549-577.

LEVITT, Peggy, and Nina GLICK SCHILLER, 2004, "Conceptualizing simultaneity: a transnational social field perspective”, International Migration Review, 38 (3): 1002- 1039.

PESSAR, Patricia R., and Sarah H. MAHER, 2003, “Transnational migration: bringing gender in”, International Migration Review, 37 (3): 812-846.

QUIJANO, Anibal, 2000, "Colonialidad del poder y clasificación social", Journal of World Systems Research, XI (2): 342-386. 
SANTOS, Boaventura de Sousa, 1995, Towards a New Common Sense: Law, Science and Politics in the Paradigmatic Transition. New York, Routledge.

SANTOS, Boaventura de Sousa, 2016, A Difícil Democracia: Reinventar as Esquerdas. São Paulo, Boitempo Editorial.

SASSEN, Saskia, 2014, Expulsions: Brutality and Complexity in the Global Economy. Cambridge and London, Harvard University Press.

SMITH, Michael Peter, and Luis Eduardo GUARNIZO (eds.), 1998, Transnationalism from Below. London and New York, Routledge.

SZANTON-BLANC, Cristina, Linda BASCH, and Nina GLICK SCHILLER, 1994, "Transnationalism, nation-state building, and culture: organizers statement”, Wenner-Gren symposium "Transnationalism, Nation-State Building, and Culture", Mijas, June 14-22, mimeo.

THOMPSON, E.P., 1963, The Making of the Working-Class. New York, Vintage Books.

VERTOVEC, Stephen, 2009, Transnationalism: Key Ideas. London, Routledge.

WIMMER, Andreas, and Nina GLICK SCHILLER, 2002, "Methodological nationalism and beyond: nation-state building, migration and the social sciences", Global Networks, 40 (2): 301-334.

WOLF, Eric, 1988, “Inventing society”, American Ethnologist, 15: 752-761. 